\title{
MEDNARODNO ZNANSTVENO SREČANJE VPETOST TURIZMA NA KMETIJI V LOKALNO IN MEDNARODNO OKOLJE
}

\section{4. - 16. junij 2012, Medana}

Turizem na kmetiji je zvrst turizma, ki v zadnjem času pridobiva na pomenu tudi $\mathrm{v}$ svetovnih okvirih. Ponudba turističnih kmetij je na številnih območjih pomemben element skupne turistične ponudbe, vendar je njen delež v turističnem gospodarstvu na državni ravni večinoma relativno skromen. Pozitivni trendi na področju turističnega povpraševanja in lokalno precejšen pomen te dejavnosti so med razlogi, da je ta pojav deležen čedalje večjega zanimanja, kar se kaže tudi v organizaciji različnih dogodkov, ki se ukvarjajo z njim. Mednje sodi tudi mednarodna znanstvena konference $\mathrm{z}$ naslovom Vpetost turizma na kmetiji v lokalno in mednarodno okolje (Agritourism between embeddedness and internationalization), ki je od 14. do 16. junija 2012 potekala v Medani. Goriška brda so bila izbrana kot mesto srečanja zaradi tega, ker gre za eno izmed tistih slovenskih pokrajin, v katerih je turizem na kmetiji najbolj razvit.

Konferenco sta organizirala Oddelek za geografijo Filozofske fakultete Univerze v Ljubljani v partnerstvu z Biotehniško fakulteto Univerze v Ljubljani ter Inštitut za geografijo Univerze v Liègeu iz Belgije. Konferenca predstavlja enega izmed rezultatov bilateral-

Slika: Udeleženci mednarodne konference o turizmu na kmetiji na Klinčevi domačiji v Medani (foto: arhiv organizatorja)

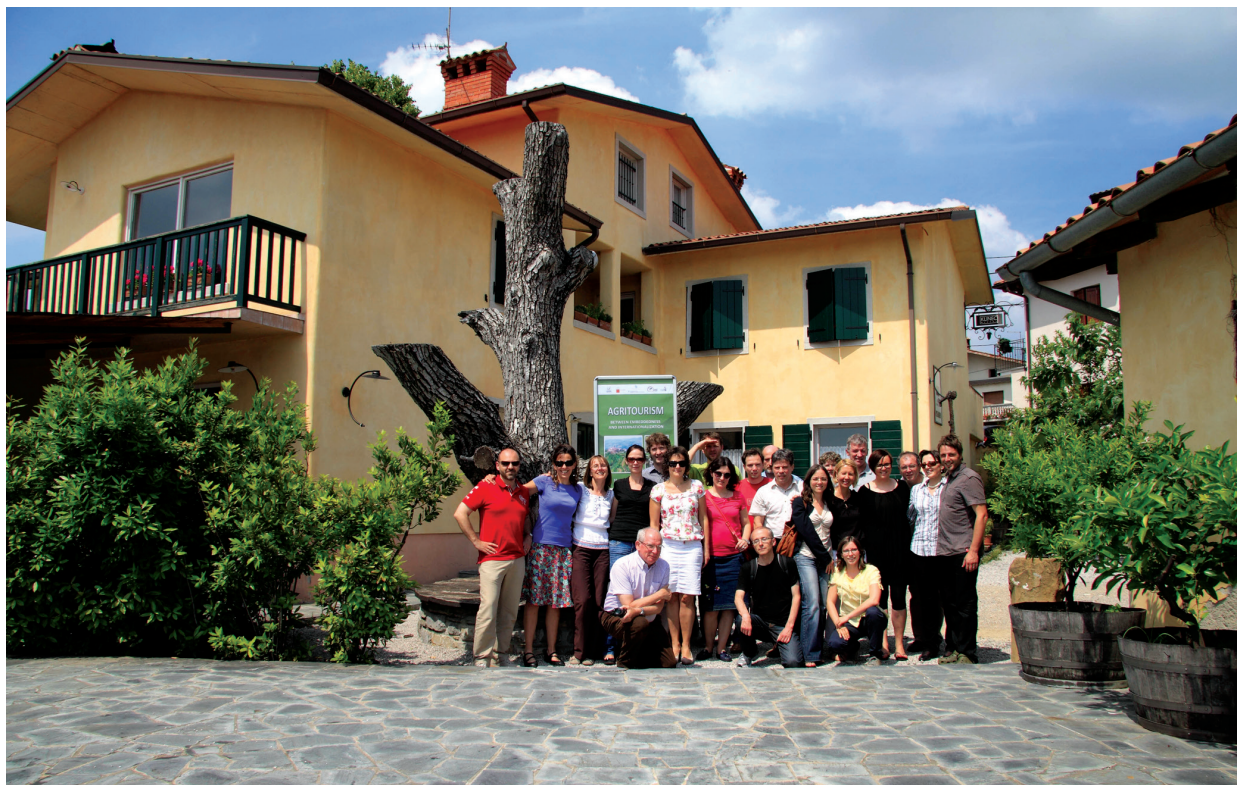


nega sodelovanja med Slovenijo in Valonsko skupnostjo v Belgiji. Izvedbo konference so podprli Agencija za raziskovalno dejavnost Republike Slovenije, Oddelek za geografijo Filozofske fakultete in Oddelek za agronomijo Biotehniške fakultete Univerze v Ljubljani, fundacija Sporck z Univerze v Liègeu (Belgija) ter organizacija Wallonia Brussels International. Podpora raznolikih ustanov kaže na širše zanimanje za vsebine, povezane s turizmom na kmetiji, in na potrebo po tovrstnih srečanjih.

Organizacija znanstvenega srečanja je rezultat večletnega znanstvenoraziskovalnega dela organizatorjev na področju razvoja podeželja in dopolnilnih dejavnosti na kmetiji, še posebej turizma na kmetiji. Sodelovanje v različnih raziskovalnih projektih in dosedanji rezultati znanstvenoraziskovalnega dela so usmerili slovenske strokovnjake k povezovanju $\mathrm{s}$ tujimi raziskovalci in k medsebojni izmenjavi izkušenj in znanja.

Zaradi želje po čim bolj celoviti obravnavi turizma na kmetiji so bili k sodelovanju povabljeni udeleženci (raziskovalci) iz različnih evropskih držav. Srečanja se je tako aktivno udeležilo 15 raziskovalcev turizma na podeželju in kmetiji iz osmih držav (Belgija, Francija, Hrvaška, Italija, Nemčija, Poljska, Slovenija, Velika Britanija). Organizatorji so si prizadevali zagotoviti udeležbo pripadnikov različnih strok, saj povezovanje geografije z drugimi strokami (ekonomisti, agrarnimi ekonomisti, ruralnimi sociologi, agronomi, sociologi idr.) pri preučevanju razvojnih teženj na podeželju omogoča zajetje različnih vsebinskih vidikov ter bolj uporabne rezultate.

Organizatorji so se odločili za kombinacijo znanstvenega sestanka z izkušnjami iz prakse, zato so bile v okvir dogodka vključene tudi predstavitve problematike s strani kmetov, kmetijskih svetovalcev za dopolnilne dejavnosti, oblikovalcev turistične ponudbe na lokalni in regionalni ravni, interesnih združenj, podpornih zavodov za razvoj podeželja, oblikovalcev politike razvoja podeželja ipd. To je znanstvenemu srečanju dalo nove razsežnosti in pozitivno vplivalo na njegove rezultate.

Na srečanju so bila v ospredju različna vprašanja, pomembna pri obravnavanju turizma na kmetiji, kot npr. vloga turizma na kmetiji znotraj turizma oziroma komplementarnost te in drugih oblik turizma, vpliv raznovrstnih geografskih dejavnikov na razvoj turizma na kmetiji, njegov odziv na spremembe na svetovnem trgu, učinki turizma na kmetiji na lokalno gospodarstvo in lokalno skupnost, značilnosti turistične ponudbe in z njo povezane spremembe idr.

Položaj in vloga turizma na kmetiji se med posameznimi državami precej razlikujeta. Ponudba turističnih kmetij je zelo raznovrstna, a razmeroma slabo prepoznavna, zato bo treba temu vprašanju v prihodnje nameniti več pozornosti. Dosedanje težnje kažejo, da je dejavnost čedalje bolj zanimiva tako za kmetovalce kot obiskovalce, zanjo pa so značilne tudi številne slabosti, npr. izrazita sezonskost, skromna zasedenost, majhno število obiskovalcev, velika konkurenca drugih oblik turistične ponudbe, počasen odziv na spreminjajoče zahteve trga itd. Ker gre za delovno zelo intenzivno dejavnost, običajno zahteva angažiranje več članov kmečkega gospodinjstva in spreminja življenjski utrip celotne družine. Po drugi strani lahko turizem gospodarsko okrepi kmetijo ali pa ji sploh omogoči preživetje, hkrati pa ima pozitivne učinke tudi na lokalno skupnost. 
Mednarodno znanstveno srečanje 'Agritourism between embeddness and internationalization' je dalo različne rezultate, med katere sodijo izdaja zbornika referatov v digitalni obliki ter načrtovane skupne objave v različnih mednarodnih revijah. Posebej je treba omeniti tudi povezovanje med različnimi domačimi (Filozofska fakulteta, Biotehniška fakulteta) in tujimi raziskovalnimi in izobraževalnimi inštitucijami, ki odpira priložnosti za nadaljnje znanstvenoraziskovalno sodelovanje, pa tudi za izmenjave študentov in profesorjev v okviru pedagoškega procesa. Izkazan interes za sodelovanje je tudi posledica relevantnosti vprašanj, povezanih s turizmom na kmetiji, ki (p)ostaja pomemben razvojni dejavnik na podeželju.

Dejan Cigale 